\title{
Vulnerable populations and inequalities in sickness and in health: The rehabilitation of the disabled and/or invalids of the Spanish Civil War
}

\author{
María-Isabel Porras-Gallo
}

\section{Introduction}

The way in which the notion of vulnerability has been defined in different ways throughout history and how different vulnerable populations have been identified in each historical period, have been the main aim of the Phoenix Tn Workshop Vulnerable populations and welfare reforms (Paris, 2008, March $\left.28^{\text {th }}-29^{\text {th }}\right)^{1}$. Although one of these previously acknowledged vulnerable populations consisted of those who suffered the impact of warfare, there is no doubt that the development of the First World War gave rise to a new vulnerable population: the disabled and invalid of that war. Faced with this problem, each country and its medical community tried to find a solution to encompass current international ideas favourable to the rehabilitation of the disabled and/or invalids, as well as to adapt to the individual circumstances of each of the countries concerned $^{2}$. As historiography has shown, the rehabilitation of civil and military

1 The main results of this interesting Phoenix Tn Workshop has been collected in Patrice Bourdelais and John Chircop, eds., Vulnerability, Social Inequality and Health, (Lisboa, 2010).

2 An idea of the different solutions adopted can be gained by consulting the following bibliography: Heather R. Perry, "Re-Arming the Disabled Veteran. Artificially Rebuilding State and Society in World War One Germany", in Katherine Ott, David Serlin and Stephen Mihm, eds., Artificial Parts, practical lives. Modern Histories Prosthetics (New York \& London, 2002), pp. 75-101; Deborah Cohen, "Will to Work: Disabled Veterans in Britain and Germany after the First World War", in David A Gerber, ed., Disabled veterans in history (Michigan, 2000), pp. 295-321; Deborah Cohen, The War come home: Disabled veterans in Britain and Germany, 1914-1939. (Berkeley, 2001); Jeffrey S. Reznick, "Work-Therapy and the Disabled British Soldier in Great Britain in the First World War: The Case of Shepherd's Bush Military Hospital, London" in David A Gerber, ed., Disabled veterans in history (Michigan, 2000), pp. 185-203; Julie Anderson, War, disability and rehabilitation in Britain, (Manchester and New York, 2011); Beth Linker, War's waste: rehabilitation in World War I, (Chicago and London, 2011). 
disabled and invalids received a considerable boost when it had to deal with the great number of victims which World War I caused in the different countries taking part in the conflict ${ }^{3}$.

Spain, although not a participant in World War I, benefited from the positive attitude to the rehabilitation of the disabled and/or invalids which was the key component of the medical model of disability prevailing at the time ${ }^{4}$. In the years immediately following World War I some doctors applied it to the disabled and invalids of the African War and to the case of those injured in work accidents ${ }^{5}$. This same philosophy was also evident when the Spanish Civil War broke out in 1936. The main aim of the present work is to show the response offered by the two opposing sides in the conflict to the problem of the disabled and invalids of the Spanish Civil War. We also intend to demonstrate the importance given to rehabilitation measures in each case, as well as to assess the role played by medical doctors, victims' associations and other sectors of society in dealing with the problem of the disabled and invalids of the Spanish Civil War, both during and, in

3 Among the many works devoted to this question, let us mention: Pascal Doriguzzi, L'Histoire politique du handicap. De l'infirme au travailleur handicapé (Paris, 1994), pp. 89-121; Henri-Jacques Stiker, Corps infirmes et sociétés (first edition, Paris: Aubier Montagne, 1982), (Paris, 1997), p. 129; Roger Cooter, "The disabled body", in Roger Cooter and John V. Pickstone, eds., Medicine in the Twentieth Century. (Amsterdam, 2000), pp. 367-383, p. 372; Claude Hamonet, Les personnes handicapées, (Paris, 2004), p. 62; David A. Gerber, ed., Disabled veterans in history (Michigan, 2000), pp. 1-51; Richard Verville, War, politics and philanthropy: the history of rehabilitation medicine (Lanham, 2009).

4 More information about the medical model of disability can be found in: Colin Barnes, Geof Mercer and Tom Shakeaspeare, Exploring disability: a sociological introduction (Cambridge, 1999), pp. 20-27.

5 José Martínez Pérez and María Isabel Porras Gallo, "Hacia una nueva percepción social de las personas con discapacidades: Legislación, medicina y los inválidos del trabajo en España (1900-1936)", Dynamis, 26 (2006), 195-219; María Isabel Porras Gallo, "La Medicina y los Seguros sociales en el abordaje del problema de los inválidos del trabajo en España en la primera mitad del siglo XX", História. Ciências, Saúde-Manguinhos, 13-2 (2006), 393-410. There is also an English version: Medicine, social security and occupational disabilities in Spain in the first half of the twentieth century. Both of them can be found on-line in: http://www.scielo.br/scielo.php?

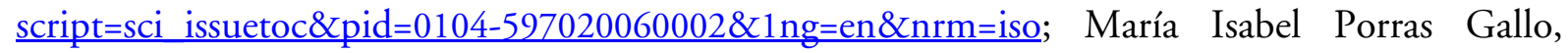
"Medicina, guerra y reintegración social del inválido del trabajo en la España del primer cuarto del siglo XX", in Ricardo Campos, Luis Montiel and Rafael Huertas, coords., Medicina, ideología e historia en España (Siglos XVI-XXI). (Madrid, 2007), pp. 525-539; María Isabel Porras Gallo, "Medicine and the social reintegration of the working disabled into the workforce in France and Spain", in Laurinda Abreu and Patrice Bourdelais, eds., The Price of Life. Welfare Systems, Social Nets and Economic Growth. (Lisboa, 2008), pp. 163-186; María-Isabel Porras-Gallo, "The role of the Spanish Red Cross in the establishment of a system of specialized health care for war disabled and invalids: from the colonial disaster to the African war", in Pilar León Sanz (ed.), Health Institutions at the Origen of the Welfare Systems in Europe, (Pamplona, 2010), pp. 131149. 
less detail, after the hostilities ${ }^{6}$. As will be shown, the treatment given and the benefits received in each case were different, especially after the end of the war. Indeed, the economic and health benefits given to the disabled and invalids of the National side were not extended by Franco's regime to those on the Republican side.

\section{The Rehabilitation of the Disabled and/or Invalids in Spain before the Civil War}

As mentioned above, the change of attitude towards disabled and invalids arising from the Great War and the social importance acquired by the professional rehabilitation of these disabled and invalids also affected Spanish society ${ }^{7}$ and, most particularly, Spanish doctors. The latter were eager to apply the measures of rehabilitation both to war disabled and to the disabled and invalids caused by work accidents or any other causes ${ }^{9}$. Indeed, in 1918 Antonio Oller (1887-1937), chiefly

6 This topic has not been analysed in detail yet. A preliminary study is included in María Isabel Porras-Gallo, "Medicina, Guerra y reintegración social del inválido del trabajo en la España de la primera mitad del siglo XX", in Ricardo Campos, Luis Montiel and Rafael Huertas, coords., Medicina, Ideología e Historia en España (Siglos XVI-XXI), (Madrid, 2007), pp. 525-539.

7 Álvaro López Núñez, Restauración social de los inválidos de la guerra. (Madrid, 1916); Álvaro López Núnez, "La reeducación de los obreros inválidos del trabajo", Anales del INP, 10 (1918), 273-275.

8 Antonio Oller, "Algunos comentarios a la Ley de accidentes del trabajo", Los Progresos de la Clínica, 12 (1918), 372-380; Joaquín Decref Ruiz, "Cirugía de guerra", Anales de la Real Academia Nacional de Medicina, 39 (1919), 109-118; Joaquín Decref Ruiz, La reeducación de inválidos para el trabajo (Madrid, 1924); Manuel Bastos Ansart, "Los resultados de la Cirugía de rehabilitación en nuestros inválidos de guerra", Anales de la Real Academia Nacional de Medicina, 44 (1924), 602-610; Manuel Bastos Ansart, "El problema de los inválidos visto a través de observaciones hechas en el Instituto Nacional de Reeducación”, Anales de la Real Academia Nacional de Medicina, 55 (1936), 209-232.

9 José Martínez Pérez and María Isabel Porras Gallo, "Hacia una nueva percepción social de las personas con discapacidades: Legislación, medicina y los inválidos del trabajo en España (1900-1936)", Dynamis, 26 (2006), 195-219; María Isabel Porras Gallo, "La Medicina y los Seguros sociales en el abordaje del problema de los inválidos del trabajo en España en la primera mitad del siglo XX", História. Ciências, Saúde-Manguinhos, 13-2 (2006), 393-410. There is also an English version: Medicine, social security and occupational disabilities in Spain in the first half of the twentieth century. Both of them can be found on-line in: http://www.scielo.br/scielo.php? script=sci issuetoc\&pid=0104-597020060002\&1ng=en\&nrm=iso; María Isabel Porras Gallo, "Medicina, guerra y reintegración social del inválido del trabajo en la España del primer cuarto del siglo XX", in Ricardo Campos, Luis Montiel and Rafael Huertas, coords., Medicina, ideología e historia en España (Siglos XVI-XXI). (Madrid, 2007), pp. 525-539; María Isabel Porras Gallo, "Medicine and the social reintegration of the working disabled into the workforce in France and Spain”, in Laurinda Abreu and Patrice Bourdelais, eds., The Price of Life. Welfare Systems, Social Nets and Economic Growth. (Lisboa, 2008), pp. 163-186. 
responsible for the creation and establishment of the speciality of Work Medicine in Spain ${ }^{10}$, censured the state for ignoring the need for the rehabilitation of those injured at work, and called for the creation of a state institution to deal with the problem $^{11}$. This request was taken into account in the draft bill of 1919 which proposed to modify the 1900 law on workplace accidents, which made no provision for the professional rehabilitation of accident victims ${ }^{12}$. However, this first attempt was unsuccessful ${ }^{13}$.

The request made by military surgeon Manuel Bastos Ansart (1887-1973) as a result of the worsening of the Moroccan War in 1921 and its consequent disabled and invalids met with greater success ${ }^{14}$. Faced with this problem this surgeon pointed out in the daily newspapers of Madrid the need to create specialised centres, including an "Institution for the rehabilitation of the wounded and disabled of the [Moroccan] campaign" ${ }^{\prime 1}$. Bastos considered this Institution to be essential to achieve the social reinsertion of war invalids, as well as the later

10 For more information about this topic, see: Ángel Bachiller Baeza, Historia de la Medicina del Trabajo en España. La obra científica del Prof. Antonio Oller Martínez. (Valladolid, 1984).

11 Antonio Oller, "Algunos comentarios a la Ley de accidentes del trabajo", Los Progresos de la Clínica, 12 (1918), 372-380.

12 Proyecto de Ley leído por el Sr. Ministro de la Gobernación modificando la de 30 de enero de 1900 sobre accidentes del trabajo, Diario de las Sesiones de las Cortes. Congreso de los Diputados, 34 (18-11-1919). Apéndice 30.

13 José Martínez Pérez and María Isabel Porras Gallo, "Hacia una nueva percepción social de las personas con discapacidades: Legislación, medicina y los inválidos del trabajo en España (1900-1936)", Dynamis, 26 (2006), 195-219; María Isabel Porras Gallo, "La Medicina y los Seguros sociales en el abordaje del problema de los inválidos del trabajo en España en la primera mitad del siglo XX", História. Ciências, Saúde-Manguinhos, 13-2 (2006), 393-410. There is also an English version: Medicine, social security and occupational disabilities in Spain in the first half of the twentieth century. Both of them can be found on-line in: http://www.scielo.br/scielo.php?

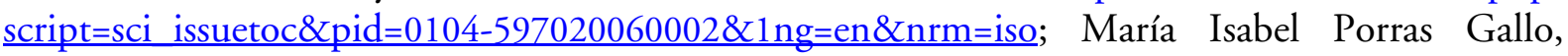
"Medicina, guerra y reintegración social del inválido del trabajo en la España del primer cuarto del siglo XX", in Ricardo Campos, Luis Montiel and Rafael Huertas, coords., Medicina, ideología e historia en España (Siglos XVI-XXI). (Madrid, 2007), pp. 525-539; María Isabel Porras Gallo, "Medicine and the social reintegration of the working disabled into the workforce in France and Spain", in Laurinda Abreu and Patrice Bourdelais, eds., The Price of Life. Welfare Systems, Social Nets and Economic Growth. (Lisboa, 2008), pp. 163-186.

14 María Isabel Porras Gallo, "Medicina, guerra y reintegración social del inválido del trabajo en la España del primer cuarto del siglo XX", in Ricardo Campos, Luis Montiel and Rafael Huertas, coords., Medicina, ideología e historia en España (Siglos XVI-XXI). (Madrid, 2007), pp. 525-539; María Isabel Porras Gallo, "Medicine and the social reintegration of the working disabled into the workforce in France and Spain", in Laurinda Abreu and Patrice Bourdelais, eds., The Price of Life. Welfare Systems, Social Nets and Economic Growth. (Lisboa, 2008), pp. 163186.

15 Manuel Bastos Ansart, "Problemas de la guerra. La rehabilitación de inutilizados", EI Sol, 8-9-1921, p. 2. 
rehabilitation of industrial accident victims in peacetime or as a result of illnesses or congenital defects. And that same year of 1921 saw the establishment of the Orthopaedic Surgery and Rehabilitation Clinic of the Military Hospital of Carabanchel (Madrid), with Manuel Bastos as its director ${ }^{16}$.

Under the influence of this favourable climate of opinion towards professional rehabilitation, the new Work Accident Law of 1922 included for the first time in Spain the professional rehabilitation of workplace invalids. To this end the Instituto de Reeducación Profesional de Inválidos del Trabajo (IRPIT) (The Institute of Professional Rehabilitation for Workplace Invalids) was set up in order to fulfil three aims: the functional readaptation, professional rehabilitation and social care of invalids (Royal Decree. Gaceta de Madrid, 5 March 1922). In order to satisfy these aims, three sections were established: medical, technical and administrative. Antonio Oller was appointed as director of the medical section. The work carried out by the IRPIT from the beginning of its activities in 1925 achieved international recognition. ${ }^{17}$ However, the negative effects of the 1929 crisis in the labour market caused the work of the IRPIT to be seriously compromised ${ }^{18}$.

The arrival of the Second Republic introduced reforms in the area of the rehabilitation of invalids and disabled. In fact, the new Work Accident Law of 1932 finally included the establishment of compulsory work accident insurance, and the

16 Manuel Bastos Ansart, De las guerras coloniales a la Guerra Civil. Memoria de un cirujano (Barcelona, 1969); José María Torres Medina, coord., Gómez Ulla. Hospital Militar Central. Cien años de Historia 1896-1996 (Madrid, 1996), pp. 136-137; Ángel Beneito Lloris, El Hospital Sueco-Noruego de Alcoi durante la Guerra Civil española. (Alcoi, 2004), pp. 105-121, María Isabel Porras Gallo, "Medicine and the social reintegration of the working disabled into the workforce in France and Spain", in Laurinda Abreu and Patrice Bourdelais, eds., The Price of Life. Welfare Systems, Social Nets and Economic Growth. (Lisboa, 2008), 163-186, p. 175.

17 Julián Palacios Sánchez, "Evolución histórica", in Julián Palacios Sánchez (coord.), Historia del C.P.E.E. de Reeducación de Inválidos. Antiguo INRI, (Madrid, undated), pp. 5159; Julián Palacios Sánchez, La institución pionera de la Rehabilitación en España, (Madrid, 1990).

18 José Martínez Pérez and María Isabel Porras Gallo, "Hacia una nueva percepción social de las personas con discapacidades: Legislación, medicina y los inválidos del trabajo en España (1900-1936)", Dynamis, 26 (2006), 195-219; María Isabel Porras Gallo, "La Medicina y los Seguros sociales en el abordaje del problema de los inválidos del trabajo en España en la primera mitad del siglo XX", História. Ciências, Saúde-Manguinhos, 13-2 (2006), 393-410. There is also an English version: Medicine, social security and occupational disabilities in Spain in the first half of the twentieth century. Both of them can be found on-line in: http://www.scielo.br/scielo.php? script=sci issuetoc\&pid=0104-597020060002\&1ng=en\&nrm=iso; María Isabel Porras Gallo, "Medicina, guerra y reintegración social del inválido del trabajo en la España del primer cuarto del siglo XX", in Ricardo Campos, Luis Montiel and Rafael Huertas, coords., Medicina, ideología e historia en España (Siglos XVI-XXI). (Madrid, 2007), pp. 525-539; María Isabel Porras Gallo, "Medicine and the social reintegration of the working disabled into the workforce in France and Spain", in Laurinda Abreu and Patrice Bourdelais, eds., The Price of Life. Welfare Systems, Social Nets and Economic Growth. (Lisboa, 2008), pp. 163-186. 
organisation of professional rehabilitation around the newly created institutions: the Caja Nacional del Seguro de Accidentes del Trabajo (National Workplace Accident Insurance Fund) and the Clínica del Trabajo (Work Clinic) ${ }^{19}$. Into the latter, responsible from that time onwards for the functional rehabilitation of workers injured in accidents, were incorporated the majority of the doctors and professionals of the old IRPIT, and Antonio Oller became its director.

For its part, the old IRPIT, now divested of the responsibility for the rehabilitation of workplace disabled, underwent considerable transformations in its functions. In fact, from 5 June 1933, it came to be known as the Instituto Nacional de Reeducación de Inválidos (INRI) (National Institute for Rehabilitation of Invalids) and broadened its aims (Decree of 5-6-1933. Gaceta de Madrid, 7-61933). Its new function was the rehabilitation of invalids and disabled of any kind (illness, congenital defects, etc). Manuel Bastos was the new director of the Institute.

In view of what we have outlined above, when the Spanish Civil War broke out Spanish society already had the background provided by the rehabilitation work carried out previously in the different institutions mentioned: Manuel Bastos' Clinic in the military hospital of Carabanchel in Madrid, the IRPIT (Institute of Professional Rehabilitation for Workplace Invalids), the Clínica del Trabajo (Work Clinic), and the INRI (National Institute for Rehabilitation of Invalids).

\section{Professional Rehabilitation and the Readaptation of Spain War Invalids}

As was to be expected, the Spanish Civil War produced a growing number of disabled and invalids to which both the Republican Government and that of the National Zone had to offer a response. Still under the influence of the initiatives set in train in other countries during the Great War, and with the background of the experience acquired with the war disabled of the Moroccan War and, above all,

19 María Isabel Porras Gallo, "La Medicina y los Seguros sociales en el abordaje del problema de los inválidos del trabajo en España en la primera mitad del siglo XX”, História. Ciências, Saúde-Manguinhos, 13-2 (2006), 393-410. There is also an English version: Medicine, social security and occupational disabilities in Spain in the first half of the twentieth century. Both of them can be found on-line in: http://www.scielo.br/scielo.php?script=sci issuetoc\&pid=0104597020060002\&1ng=en\&nrm=iso; María Isabel Porras Gallo, "Medicina, guerra y reintegración social del inválido del trabajo en la España del primer cuarto del siglo XX", in Ricardo Campos, Luis Montiel and Rafael Huertas, coords., Medicina, ideología e historia en España (Siglos XVIXXI). (Madrid, 2007), pp. 525-539; María Isabel Porras Gallo, "Medicine and the social reintegration of the working disabled into the workforce in France and Spain", in Laurinda Abreu and Patrice Bourdelais, eds., The Price of Life. Welfare Systems, Social Nets and Economic Growth. (Lisboa, 2008), pp. 163-186. 
with workplace invalids, an attempt was made to establish measures (limited by the conditions) to face up to the situation in hand and the demands of those affected.

\section{From the demands of the League of War Disabled and Invalids to the "Centre for Orthopaedic Surgery and War Wound Recovery" of the Swedish-Norwegian Hospital of Alcoy}

On the Republican side these demands were channelled through the "League of the Disabled and Invalids of the War in Spain" and the different committees set up in some provinces and regions of Spain; but this matter was also dealt with by some Spanish doctors and others from outside who formed part of the International Brigades. In both cases, functional and professional rehabilitation were considered key points in responding to the problem of the disabled and invalids of the Civil War and their subsequent reintegration into society. The creation of the National League of War Disabled and Invalids in 1937 in Madrid reflected the favourable climate towards rehabilitation at that time, and the conviction that professional rehabilitation could change the status of the disabled. In fact, one of the main aims of the League was "to educate and re-educate the disabled physically and culturally" ${ }^{20}$. The League insisted that they did not want to be "humiliated invalids or parasites", but they wanted to be "educated, useful invalids, in spite of our disability". For this reason one of their first demands was the setting up of "residences for education and rehabilitation as far as possible, to educate all those invalids who may require it" ${ }^{21}$. In their opinion, this demand should be urgently debated in the National Congress of the League which was soon to be held. The Congress took place in Valencia in August 1938, and was the official founding moment of the League, which from that moment on took the name of "League of War Disabled and Invalids of the Army of the Republic" ${ }^{22}$.

The need to carry out a broader and more detailed analysis of the problems of the war-disabled and the solutions they called for led to the setting up of different local Committees. In the absence of new data which may be produced by on-going research, we can confirm that some of them, such as the Liga de Euzkadi de Mutilados e Inválidos de Guerra (the Basque League of War Disabled and Invalids), or the Committees in Barcelona or Cartagena played an outstanding part right from the beginning of the conflict -a part which became even more important

20 Federación Española-Liga de Mutilados e Inválidos de Guerra, Material para la discusión para el Pleno Nacional de la Liga de Mutilados e Inválidos de Guerra (Madrid, 1937), p. 3

21 Ibid.

22 Antonio Bravo and Antonio Tellado, Los mutilados del ejército de la República (Madrid, 1976); Antonio Trabal, Breve historial de la Liga de Mutilados e Inválidos de la Guerra de España (Barcelona, 1986). 
from 1938 onwards. They quickly organized help for the disabled, which included economic assistance to cover basic necessities, but also the provision or subsidy of any orthopaedic devices required. They likewise dealt with the design and/or opening of centres of functional and/or professional rehabilitation ${ }^{23}$.

Meanwhile, among the foreign doctors who formed part of the International Brigades, mention should be made of the psychiatrist Max Hodann who, as well as carrying out a novel experiment in the field of psychiatric rehabilitation ${ }^{24}$, offered an interesting programme for dealing with the problem of the rehabilitation of war disabled in $1938^{25}$. This programme was based on the experience gained in the First World War and on the knowledge that Hodann had of the rehabilitation activity carried out in Spain before the Civil War. This background allowed Hodann to formulate his proposal along three basic lines: 1) the creation of "rehabilitation centres with workshops to rehabilitate the wounded in different professions, together with the possibility of providing surgical treatment"; 2) the preparation of a census of Army amputees and invalids; and 3) the application of the economic and rehabilitation benefits of the 1932 Law of Compulsory Insurance of Workplace Accidents to the disabled and invalids of the Civil War ${ }^{26}$. In accordance with this plan, the cases of "partial permanent incapacity for normal profession" and those of "permanent and total incapacity for normal profession" should receive the benefits of professional rehabilitation, while cases of "temporary incapacity" and those of "permanent and absolute incapacity for any work" would be excluded. The latter would only have the right to medical assistance and pensions as established by law.

Hodann considered it essential that the Rehabilitation Centres which were set up should have the cooperation not only of surgeons, teachers and craftsmen, but also of representatives of the disabled and wounded. An essential part of these centres was the setting up of workshops for the manufacture of artificial limbs with craftsmen expert in the construction of orthopaedic apparatus adapted to wartime requirements. Hodann thus found it expedient to establish close links with the National League of War Disabled and Invalids, in order to gain access to

23 Archive of the Civil War of Salamanca, Liga de Mutilados, Inválidos y Viudas de la Guerra de España en Francia and Archive of the Civil War of Salamanca, Sección Santander, C.574, Exp.3

24 Cándido Polo Griñán, "La Psiquiatría en las Brigadas Internacionales", in Ricardo Campos, Olga Villasante and Rafael Huertas, eds., De la 'Edad de Plata' al exilio. Construcción y 'reconstrucción' de la Psiquiatría española (Madrid, 2007), pp. 211-237.

25 Max Hodann, "El problema de la reeducación de los mutilados de guerra", La Voz de la Sanidad, 6 (31-5-1938), 5-6; Max Hodann, "El problema de la reeducación de los mutilados de guerra", La Voz de la Sanidad, 7 (18-7-1938), 9-10; Max Hodann, "Informe respecto al problema de la reeducación de los mutilados de guerra, Valencia", Alameda, 15 (1938), p. III.

26 Max Hodann, "El problema de la reeducación de los mutilados de guerra", La Voz de la Sanidad, 6 (31-5-1938), 5-6, p. 6; Max Hodann, "El problema de la reeducación de los mutilados de guerra", La Voz de la Sanidad, 7 (18-7-1938), 9-10, p. 9. 
orthopaedic craftsmen and specialised workshops. Another vital element was the acquisition of the necessary raw materials for the manufacture of these items.

Clearly, one of the possible ways to respond to the requests of the National League of War Disabled and Invalids, and to act in accordance with the ideas put forward by Hodann and other doctors, was to make use of the existing specialised centres such as the Orthopaedic Surgery and Rehabilitation Clinic of the Military Hospital of Carabanchel (Madrid), the INRI (National Institute for Rehabilitation of Invalids) or the Clínica del Trabajo (Work Clinic). All of these remained within the Republican zone until June 1937 when the Nationalist forces reached the southern outskirts of Madrid. However, their use as rehabilitation centres seems doubtful. In fact, the Clinic of the Military Hospital, being so close to the front line, was dismantled and transferred to the Palace Hotel in the centre of Madrid ${ }^{27}$, the Work Clinic became a field hospital ${ }^{28}$ and the surgical equipment of the INRI was transferred to field hospitals ${ }^{29}$.

Without going much further into the matter, we may mention one of the main initiatives taken on the Republican side in response to the demands we have just seen. This was the initiative taken by the surgeon Bastos Ansart in the SwedishNorwegian International Brigade Hospital in Alcoy from 27 August $1937^{30}$. Upon his arrival in this hospital Manuel Bastos took it upon himself to organise a "Centre for Orthopaedic Surgery and War Wound Recovery" which, according to Beneito ${ }^{31}$, carried out the same functions as those of the Orthopaedic Surgery and Rehabilitation Clinic of the Military Hospital of Carabanchel (Madrid) of which this surgeon had been the director. This involved not only operating on the wounded, but also dealing with the adaptation of the appropriate artificial limbs and the rehabilitation of the disabled. Continual bombing forced the closure of the

27 Manuel Bastos Ansart, De las guerras coloniales a la Guerra Civil. Memoria de un cirujano (Barcelona, 1969); Ángel Beneito Lloris, El Hospital Sueco-Noruego de Alcoi durante la Guerra Civil española. (Alcoi, 2004); Ángel Beneito Lloris, "La ayuda escandinava y el hospital sueco-noruego de Alcoi”, in Manuel Requena Gallego and Rosa María Sepúlveda, coords., La Sanidad en las Brigadas Internacionales (Cuenca, 2006), pp. 131-160.

28 Antonio Oller, Memoria de la Clínica del Trabajo del INP (1933-1934) (Madrid, 1935); Antonio Oller, Memoria de la Clínica del Trabajo del INP (1935) (Madrid, 1936); Ángel Bachiller Baeza, La Medicina Social en España (El Instituto de Reeducación y la Clínica del Trabajo 1922-1937) (Valladolid, 1985), pp. 41-78.

29 General Military Archive of Avila, C2323, L.46, Cp21.

30 The Scandinavians asked Bastos to take on the management of the SwedishNorwegian Hospital in Alcoy once his agreed collaboration with them had finished. Bastos refused the directorship, but did accept the directorship of the Hospital's surgical team. Ángel Beneito Lloris, El Hospital Sueco-Noruego de Alcoi durante la Guerra Civil española. (Alcoi, 2004), pp. 70 and 115.

31 Ángel Beneito Lloris, El Hospital Sueco-Noruego de Alcoi durante la Guerra Civil española. (Alcoi, 2004), pp. 71, 116-117. 
Alcoy Hospital in November $1938^{32}$. Bastos, together with some of his patients, moved to a small Convalescent Centre in Villa Joyosa (Alicante). The centre, enlarged and equipped with the material recovered from Alcoy, was used until the end of the War and the arrest of Bastos on 6 April 1939. This traumatic end signalled the harsh and sorry fate which awaited the war disabled of the Republican side after the establishment of Franco's regime at the end of the war, at which we shall look more closely later.

\section{Rehabilitation initiatives of the Nationalist group during the war, and the design of a general plan for "Reorientation and professional placement of War Disabled", to be applied by the new regime}

On the Nationalist side, the Decree of 23-1-1937 (BOE, 24-1-1937) set up the "General Directorate for War Invalids of the Fatherland" (Dirección General de Mutilados de Guerra por la Patria). Its aim was to organise the "Honourable Corps of War Disabled" (Honorable Cuerpo de Mutilados de Guerra), as well as the classification, rehabilitation, legal organisation, placement, and care of its members. Important elements for the achievement of these goals were "the creation and establishment of Offices of Professional Rehabilitation", where the War Disabled would be trained in new activities, as well as "proposing the positions which were to be reserved for the members of the Corps of War Disabled in State, Provincial and Municipal bodies" ${ }^{34}$. This decree led to the progressive establishment of pensions and to the development of certain rehabilitation initiatives (initially very limited), but the process was not without its difficulties. Documents consulted in the General Military Archive of Avila show the problems presented in applying the Decree of 1937. It was quite difficult to carry out the medical examinations, establish the invalidity and its seriousness, deal quickly with invalidity reports and thus award pensions to help the disabled to survive ${ }^{35}$.

Problems also arose in providing the functional and professional rehabilitation of the disabled and invalids. At an early stage, some groups put forward suggestions to help resolve these difficulties: for example, in April 1937, the National Health Headquarters of the Requetés (the Carlist National Council) proposed the creation

32 Ángel Beneito Lloris, El Hospital Sueco-Noruego de Alcoi durante la Guerra Civil española. (Alcoi, 2004).

33 Ángel Beneito Lloris, El Hospital Sueco-Noruego de Alcoi durante la Guerra Civil española. (Alcoi, 2004), pp. 73-74, 118-119.

34 Article 2 of Decree of 23-1-1937; Benito Nogales Puertas, La Reorientación y colocación profesional de mutilados de Guerra (Estudio de Organización Nacional) (Santiago, 1939), p. 47.

35 General Military Archive of Avila, C.2326, L.50.Cp88, and C2326, L.50, Cp.91. 
of a National Institute of Orthopaedics and Rehabilitation of War Wounded ${ }^{36}$. This was justified by the existence of some 26,750 invalids needing rehabilitation at that moment, and it was proposed that it should be installed in the Zaragoza Military Academy or in the Infantry Barracks of Astorga to keep costs down. This initiative was turned down on the basis that an institution of this kind, the INRI, already existed. It had just been liberated in June 1937, and it was necessary to carry out a census of the disabled in order to evaluate possible requirements. In fact, the INRI's proximity to the front line, its deteriorated condition and the confiscation of its surgical equipment meant that it was inoperative during the conflict. ${ }^{37}$ On the other hand, it appears that early in January 1938 two rehabilitation centres for the disabled were set up for the natives in Tetuan and Melilla ${ }^{38}$. In the same month the Istituto Rizzoli of Bologna, in Italy, offered twelve places for the rehabilitation of officers and leaders of the Nationalist group, although only two of them were taken up due to economic constraints ${ }^{39}$. During 1938 rehabilitation centres were set up in Oza (La Coruña) and in certain military hospitals such as those of San Sebastian, Seville and Zaragoza.

The problem of the disabled acquired greater importance after 1938, and particularly in 1939: in January there was a Census of Disabled ${ }^{40}$, on 2 February the Gran Patronato de Asistencia a Frentes y Hospitales (Grand Foundation for Assistance to Battle Fronts and Hospitals) was set up, and on 2 April the Statute of the Honourable Corps of War Disabled was enacted ${ }^{41}$. The latter included a comprehensive list of injuries for the classification of the disabled (fit, potential, permanent and absolute) and made definitive provision for their professional placement. One result of these two legislative initiatives of 1939 was the creation of the "Service of Recovery of War Disabled for [civilian] Work", and the establishment in the Military Hospital of San Sebastian of the first Vocational Guidance Office $^{42}$. This office was created partly on the basis of the material and

36 General Military Archive of Avila, C.2323, L.46, Cp.21.

37 Julián Palacios Sánchez, "Evolución histórica", in Julián Palacios Sánchez (coord.), Historia del C.P.E.E. de Reeducación de Inválidos. Antiguo INRI, (Madrid, undated), pp. 51-59; Julián Palacios Sánchez, La institución pionera de la Rehabilitación en España, (Madrid, 1990).

38 General Military Archive of Avila, C.2380, L.158, Cp.25.

39 General Military Archive of Avila, C.2323, L.45, Cp.51.

40 General Military Archive of Avila, C2326, L.50, Cp.91.

41 Benito Nogales Puertas, La Reorientación y colocación profesional de mutilados de Guerra (Estudio de Organización Nacional) (Santiago, 1939), pp. 46-57.

42 Benito Nogales Puertas, La Reorientación y colocación profesional de mutilados de Guerra (Estudio de Organización Nacional) (Santiago, 1939), pp. 127-128; General Military Archive of Avila, C2344, L.86, Cp.29. 
staff already employed in the State Office attached to the Apprentice School. Similar offices were located in the hospitals of Bilbao, Zaragoza and La Coruña ${ }^{43}$.

The management of the Orthopaedic and Rehabilitation Services was in the hands of orthopaedic surgeons and traumatologists from the military or civilian health services, who had generally gained experience in the military field - in Bastos' Clinic in Carabanchel- or in the different institutions mentioned above [the Institute of Professional Rehabilitation for Workplace Invalids (IRPIT), the National Institute for Rehabilitation of Invalids (INRI) or the Work Clinic], with invalids from the workplace or elsewhere ${ }^{44}$. One of these was Mario Oliveras Devesa $^{45}$, the Head of the Orthopaedic and Rehabilitation Service of the General Mola Military Hospital in San Sebastian ${ }^{46}$. The limited data currently available makes it difficult for us to evaluate the role performed by these services during the war and their results.

What we do know for certain is that at the end of the war it was these same professionals who, either on their own initiative or on the occasion of the holding of the First Commission on the Recovery of War Disabled ${ }^{47}$, pointed out the need to establish and/or maintain "Centres of Orthopaedic Surgery and Rehabilitation" in order to deal with "the problem of the treatment of all the residual wounds of the members, and the rehabilitation of the disabled" ${ }^{48}$. They even drew up a general national organisation plan for the "Reorientation and Professional Placement of War Disabled" ${ }^{\prime 4}$, which excluded those from the Republican side ${ }^{50}$.

43 Benito Nogales Puertas, La Reorientación y colocación profesional de mutilados de Guerra (Estudio de Organización Nacional) (Santiago, 1939), pp. 127-130 et seq.

44 Benito Nogales Puertas, La Reorientación y colocación profesional de mutilados de Guerra (Estudio de Organización Nacional) (Santiago, 1939), pp. 153-157; Mario Oliveras Devesa, "La Reeducación funcional protésica en los amputados de brazo", Revista Española de Medicina y Cirugía de Guerra, 2 (1938), 91-102, p. 92.

45 Mario Oliveras Devesa, La recuperación de mutilados (San Sebastián, 1939); Mario Oliveras Devesa, Traumatismos e incapacidades de la mano (Barcelona, 1948).

46 Mario Oliveras Devesa, La recuperación de mutilados (San Sebastián, 1939). The author refers to earlier (1924) works of his concerning his experience with workplace accident victims.

47 Primera Ponencia, Recuperación quirúrgico-ortopédica de los mutilados de guerra, (Madrid, 1941).

48 J. Pruneda, "Los Servicios de Cirugía Ortopédica y Reeducación", Revista Española de Medicina y Cirugía de Guerra, 15 (1939), 372-376, p. 372. Pruneda's previous experience had been acquired in the Orthopaedic Surgery and Rehabilitation Clinic of the Military Hospital of Carabanchel in the six years prior to the war.

49 Benito Nogales Puertas, La Reorientación y colocación profesional de mutilados de Guerra (Estudio de Organización Nacional) (Santiago, 1939), pp. 29-37.

50 Antonio Bravo and Antonio Tellado, Los mutilados del ejército de la República (Madrid, 1976); Antonio Trabal, Breve historial de la Liga de Mutilados e Inválidos de la Guerra de España (Barcelona, 1986). 
According to the project drawn up by Lieutenant Nogales Puertas (1939), Doctor of the Army Medical Corps and Medical Inspector of the National Workplace Accident Insurance, the National Plan for "Reorientation and Professional Placement of War Disabled" should be centred on five key elements: 1) Centres and Institutes for functional Rehabilitation and Prosthetics; 2) the Central and Provincial Offices of Vocational Guidance 3) the Central and Provincial Offices and premises dealing with Professional Rehabilitation; 4) the Central and Provincial Offices of Professional Placement; and 5) the establishment of a Board of Social and Professional Guardians of the War Disabled ${ }^{51}$.

As was to be expected under a regime such as that of Franco, these Offices, Commissions, and the Board itself included representatives of the ministries concerned in each case; of the Instituto Nacional de Previsión (INP) (National Social Security Institute); of the Army Medical Corps; of the Trades Union Delegations of the Falange Española Tradicionalista de las JONS (the only legally permitted political party), and of the Vertical Trade Unions; of the "Corps of Gentlemen Disabled in the Patriotic War"; of the Church and the religious orders involved in the plan; of the Private Banks, the Chambers of Commerce and of the Employers' Federations, etc. The plan included the maintenance of the pensions which had been conceded since the end of 1937, and the application of the workplace accident law of 1932 to deal with some cases such as that of the disabled whose social rehabilitation consisted of self-employment, rather than obtaining work with a third party.

In addition to the clear political and religious connotations of this plan, it should be made clear that its practical realisation called for the use of all existing public resources, and the need to seek the aid of private enterprise (industrial, Private Banking, and private religious Professional Colleges) in order to deal exclusively with the problem of the disabled from the Nationalist side of the Spanish Civil War, at a time of great economic hardship as suffered in post-war Spain.

\section{Vulnerability and Inequalities of the War Disabled after the Spanish Civil War}

While not going too far into the degree of practical implementation of the reorientation and professional rehabilitation programme for the disabled veterans of the Nationalist side, we may point out that functional rehabilitation was based around four centres set up in Madrid, San Sebastian, Barcelona and Tetuan. Here they carried out reparative and orthopaedic operations, and provided the necessary

51 Benito Nogales Puertas, La Reorientación y colocación profesional de mutilados de Guerra (Estudio de Organización Nacional) (Santiago, 1939). 
artificial limbs. Now, as certain doctors of the Army Medical Corps pointed out, this process was far from easy and required a greater quantity of resources and medical specialisation ${ }^{52}$. They likewise considered necessary a great deal of coordination in order to begin professional rehabilitation as soon as possible, and to achieve the return to the civil workforce of the re-educated veterans, which was not always the case.

In order to achieve this later objective, the Law of 25 August 1939 (Spanish Official Gazette 1 September) approved preferential access to public employment for the disabled, veterans and ex-prisoners of war, as well as for the families of war victims from the Nationalist side. Indeed, $80 \%$ of the vacancies in the lower levels of staff of the different administrative services were reserved for them, as well as a guaranteed number of positions of responsibility in the civil service for those who had taken entrance examinations, and $80 \%$ of the positions as doormen, janitors and receptionists in public buildings ${ }^{53}$.

To the foregoing were added the pensions granted in each case, according to the Law of the Disabled of War for the Homeland and the regulations of the Corps of Military Invalids. In addition to the legal measures brought into force during the Civil War, two new laws -that of 12 December 1942 and that of 26 December 1958- regulated the economic assistance to be received by the wounded and disabled of the Nationalist Army ${ }^{54}$. All this provided a solution to the situation of the war disabled and invalids of the Nationalist zone.

The fate suffered by the Republican disabled and invalids was very different ${ }^{55}$. If those who remained in Spain had to subsist basically on charity, those who went into exile had no less difficulty. The "League of the Wounded and Disabled of the War in Spain" ${ }^{\prime 56}$ was abolished at the end of the Civil War. In common with half a million Spaniards, the League went into exile in France, which gave it a cool reception until the end of the Second World War. Between 1939 and 1945 Republican disabled and invalids had to put up with extremely harsh conditions, and attempts made by some of the leaders of the League to mitigate their situation did not always meet with success. In fact, initially they received none of the economic support requested from the Republican Government in Exile in order to

52 Manuel Gómez-Durán, "Recuperación quirúrgico-ortopédica de los mutilados de guerra. Exposición general del problema”, in Primera Ponencia, Recuperación quirúrgicoortopédica de los mutilados de guerra, (Madrid, 1941), pp. 7-26.

53 Manuel Valdés Larrañaga, De la Falange al Movimiento (1936-1952) (Madrid, 1994), p. 134.

54 Ángel Ruano Hernández, Invalidez, desamparo e indefensión en seres humanos (Madrid, 1993), p. 69.

55 Antonio Bravo and Antonio Tellado, Los mutilados del ejército de la República (Madrid, 1976); Antonio Trabal, Breve historial de la Liga de Mutilados e Inválidos de la Guerra de España (Barcelona, 1986); Pedro Vega, Historia de la Liga de Mutilados (Madrid, 1981).

56 In the National Congress held in Valencia in 1938 it was decided also to include the disabled of the Nationalist side. 
set up residences for the Republican disabled and invalids in France. After long negotiations, the League finally succeeded in obtaining three residences in France, which were to be lost when the French army was defeated by Germany. It was not until after the liberation of Paris that the exiled Spanish disabled veterans were able to set up a "Committee for the Reorganisation of the League of the Wounded and Disabled of the War in Spain". This committee asked for funds from Pablo Picasso and Pau Casals to prepare the National Congress of the Disabled of the War in Spain, which took place in Toulouse in 1945 and marked the relaunching of the activities of the League.

The steps taken by the League from that moment onwards permitted an improvement in the situation of the Republican disabled and invalids. One of the first successes was the application of the Cordonnier Law to Spanish double amputees. In addition, the French Government Decree of 7 May 1947 authorised Spanish doctors to give professional help to exiles of their own nationality, including disabled and invalids, through the Spanish Republican Red Cross (independent from that operating in Spain), which set up 90 dispensaries distributed throughout various major French cities. Each dispensary had a staff of specialists, and in Toulouse there was an orthopaedic workshop to produce artificial $\operatorname{limbs}^{57}$. As well as this, there were the trade apprenticeship courses which the French government offered continuously to exiled Spanish disabled and invalids, in order to help their rehabilitation for work. The French government also helped to set up different co-operative societies (such as the Société Coopérative Sandalière of Bordeaux and its successor the Coopérative Ouvrière de la Chaussure), run by members of the League of the Wounded and Disabled, in which work and wages were provided to the exiled and disabled veterans from the Civil War ${ }^{58}$.

The League of the Wounded and Disabled of the War in Spain sought to achieve the reinsertion of disabled and invalids into day-to-day French life, and between 1949 and 1977 provided regular subsidies to their neediest members, acquiring work for them by means of formulae such as the cooperatives mentioned above, loans and special grants, medical attention (the purchase of prosthetics and orthopaedic devices) and help in administrative tasks, such as the preparation of official and private documents 59 .

57 Francisco Guerra, La medicina en el exilio republicano (Alcalá de Henares, 2003), pp. 203-208.

58 Antonio Bravo and Antonio Tellado, Los mutilados del ejército de la República (Madrid, 1976); Antonio Trabal, Breve historial de la Liga de Mutilados e Inválidos de la Guerra de España (Barcelona, 1986); Archive of the Civil War of Salamanca, Liga de Mutilados, Inválidos y viudas de la Guerra de España en Francia

59 Antonio Bravo and Antonio Tellado, Los mutilados del ejército de la República (Madrid, 1976); Antonio Trabal, Breve historial de la Liga de Mutilados e Inválidos de la Guerra de España (Barcelona, 1986); Archive of the Civil War of Salamanca, Liga de Mutilados, Inváli- 
Both the Spanish Socialist Party (PSOE) and its trade union (UGT) came to the aid of the Republican war-disabled and invalids through their participation in the co-operative societies, and through the creation of the charitable institution 'Solidaridad Democrática Española'. From this organisation they tried by all legal means possible to ensure supplies of material and health assistance, and to give protection and legal advice to all Spanish citizens living in France, and to those still living in Spain.

Unsuccessful attempts were made right from the end of the Civil War until 1975 to rectify the situation of inequality which obtained between the rights and treatment granted to war disabled from the Nationalist zone and those from the Republican zone. In fact, conversations held between the League of the Wounded and Disabled and the Director-General of the Corps of Gentlemen Disabled in the Patriotic War broke down in 1939. A similar fate befell the demands made by the League from 1967 onwards to achieve "complete physical and moral rehabilitation for the disabled of the Republican Army", and the corresponding pensions ${ }^{60}$.

It was not until 1975 that the first necessary legislative steps were taken to deal with the demands put forward by the Republican disabled and invalids. The first legislation came in $1976^{61}$ and in the early eighties ${ }^{62}$, but the situation was not finally settled until $1986^{63}$. This implied, among other things, the concession of almost 50.000 pensions at a cost of almost 3,345 million euros between 1977 and 2005 inclusive.

\section{Final Comments}

Throughout these pages we have been able to see how the unfolding of the First World War gave rise to a vulnerable population: the disabled and invalids of that war. As the nations taking part in the strife faced up to this problem, there came

dos y viudas de la Guerra de España en Francia; Archive of the Civil War of Salamanca, Liga de Mutilados e Inválidos de la Guerra de España en Madrid

60 Antonio Bravo and Antonio Tellado, Los mutilados del ejército de la República (Madrid, 1976).

61 Decree 670/1976, of 5 March, by which pensions were granted to Spaniards who, having been wounded in the last War, were unable to become members of the Corps of Gentlemen Disabled in the Patriotic War; Royal Decree- Law 43/1978, of 21 December directed to war veterans irrespective of whether they belonged to one side or the other of the conflict.

62 Law 35/1980, of 26 June, concerning pensions to disabled veterans of the Republican Zone; Royal Decree 31/1982, of 12 February, integrating disabled veterans of the Republican zone into the Social Security system for purposes of medical attention and social services; Law 6/1982, of 29 March, concerning pensions to civilian war disabled.

63 Laws such as 37/1984, popularly known as the law "of Republican soldiers", or Law $18 / 1984$. 
about a general climate of opinion favourable to the functional and professional rehabilitation of the disabled in order to encourage their later reintegration into society. The medical community of each country played an important part, with the prevalence of the medical or individual model of disability.

This culture of professional rehabilitation of disabled and invalids also spread to Spain, where medical doctors applied it to the disabled from the War of Morocco and, above all, to the victims of workplace accidents. The Spanish Civil War produced another vulnerable population, to whom measures of functional and professional rehabilitation would be applied. Both sides took measures calling on the background and experience previously obtained in the field of professional rehabilitation. Of course, the characteristics of the war dictated certain differences in the availability of resources and the procedures applied on each of the two sides during the war: nevertheless, the real inequalities came about at the end of the hostilities. The disabled and invalids of the Nationalist zone received moral recognition, and benefited from a functional and professional re-education programme (albeit very limited), preferential access to jobs in public buildings and in the Spanish Administration, as well as a system of pensions. Those from the Republican zone, however, were excluded from this programme and the majority of them, as exiles, had to fight for almost 50 years to survive and to achieve parity with those of the other side. During this time the exiles in France depended on the work of the "League of the Wounded and Disabled of the War in Spain", and aid provided by the French government, by international organisms such as the Spanish Republican Red Cross, by left wing political parties and trade unions and by artists such as Pablo Picasso and Pau Casals.

The case I have analysed here allows us to underline the important role played by cultural, economic, social and, most particularly, political factors in the construction of vulnerabilities and inequalities. We must take historical experience into account to apply it to our present-day life.

Maria-Isabel Porras-Gallo is Senior Lecturer in History of Science at the Department of Medical Sciences and Ciudad Real Faculty of Medicine, at CastillaLa Mancha University, Spain.

\section{Acknowledgements}

This work has been carried out within Project No PAI05-009 of the Department of Education and Science of the Junta of Castilla-La Mancha and with the help of the University of Castilla-La Mancha (Programme of translations and revisions of scientific articles, No TR20080879). A preliminary version of this paper has been presented on the PHOENIX TN Workshop Vulnerable populations and welfare reforms (Paris, 2008, March 28th-29th). 


\section{References}

Anderson, Julie, War, disability and rehabilitation in Britain, (Manchester and New York, 2011).

Bachiller Baeza, Ángel, Historia de la Medicina del Trabajo en España. La obra científica del Prof. Antonio Oller Martínez. (Valladolid, 1984).

Bachiller Baeza, Ángel, La Medicina Social en España (El Instituto de Reeducación y la Clínica del Trabajo 1922-1937) (Valladolid, 1985).

Barnes, Colin, Mercer, Geof and Shakeaspeare, Tom, Exploring disability: a sociological introduction (Cambridge, 1999).

Bastos Ansart, Manuel, "Problemas de la guerra. La rehabilitación de inutilizados", El Sol, 8-9-(1921), p. 2.

Bastos Ansart, Manuel,"Los resultados de la Cirugía de rehabilitación en nuestros inválidos de guerra", Anales de la Real Academia Nacional de Medicina, 44 (1924), 602-610.

Bastos Ansart, Manuel,"El problema de los inválidos visto a través de observaciones hechas en el Instituto Nacional de Reeducación”, Anales de la Real Academia Nacional de Medicina, 55 (1936), 209-232.

Bastos Ansart, Manuel, De las guerras coloniales a la Guerra Civil. Memoria de un cirujano (Barcelona, 1969).

Beneito Lloris, Ángel, El Hospital Sueco-Noruego de Alcoi durante la Guerra Civil española. (Alcoi, 2004).

Beneito Lloris, Ángel,"La ayuda escandinava y el hospital sueco-noruego de Alcoi”, in Manuel Requena Gallego and Rosa María Sepúlveda, coords., La Sanidad en las Brigadas Internacionales (Cuenca, 2006), pp. 131-160.

Bourdelais, Patrice and Chircop, John, eds., Vulnerability, Social Inequality and Health, (Lisboa, 2010).

Bravo, Antonio and Tellado, Antonio, Los mutilados del ejército de la República (Madrid, 1976).

Cohen, Deborah, "Will to Work: Disabled Veterans in Britain and Germany after the First World War", in Gerber, David A, ed., Disabled veterans in history (Michigan, 2000), pp. 295-321.

Cohen, Deborah, The War come home: Disabled veterans in Britain and Germany, 1914-1939. (Berkeley, 2001).

Cooter, Roger,"The disabled body", in Roger Cooter and John V. Pickstone, eds., Medicine in the Twentieth Century. (Amsterdam, 2000), pp. 367-383.

Decref Ruiz, Joaquín, "Cirugía de guerra", Anales de la Real Academia Nacional de Medicina, 39 (1919), 109-118.

Decref Ruiz, Joaquín, La reeducación de inválidos para el trabajo (Madrid, 1924). 
Doriguzzi, Pascal, L'Histoire politique du handicap. De l'infirme au travailleur handicapé (Paris, 1994).

Federación Española-Liga de Mutilados e Inválidos de Guerra, Material para la discusión para el Pleno Nacional de la Liga de Mutilados e Inválidos de Guerra (Madrid, 1937).

Gerber, David A, ed., Disabled veterans in history (Michigan, 2000).

Gómez-Durán, Manuel, "Recuperación quirúrgico-ortopédica de los mutilados de guerra. Exposición general del problema", in Primera Ponencia, Recuperación quirúrgico-ortopédica de los mutilados de guerra, (Madrid, 1941), pp. 7-26.

Guerra, Francisco, La medicina en el exilio republicano (Alcalá de Henares, 2003).

Hamonet, Claude, Les personnes handicapées, (Paris, 2004).

Hodann Max, "El problema de la reeducación de los mutilados de guerra", La Voz de la Sanidad, 6 (31-5-1938), 5-6.

Hodann, Max, "El problema de la reeducación de los mutilados de guerra", La Voz de la Sanidad, 7 (18-7-1938), 9-10.

Hodann, Max, "Informe respecto al problema de la reeducación de los mutilados de guerra, Valencia”, Alameda, 15 (1938), p. III.

Linker, Beth, War's waste: rehabilitation in World War I, (Chicago and London, 2011).

López Núñez, Álvaro, Restauración social de los inválidos de la guerra. (Madrid, 1916).

López Núñez, Álvaro, "La reeducación de los obreros inválidos del trabajo", Anales del INP, 10 (1918), 273-275.

Martínez Pérez, José and Porras Gallo, María Isabel "Hacia una nueva percepción social de las personas con discapacidades: Legislación, medicina y los inválidos del trabajo en España (1900-1936)", Dynamis, 26 (2006), 195-219.

Nogales Puertas, Benito, La Reorientación y colocación profesional de mutilados de Guerra (Estudio de Organización Nacional) (Santiago, 1939).

Oliveras Devesa, Mario "La Reeducación funcional protésica en los amputados de brazo", Revista Española de Medicina y Cirugía de Guerra, 2 (1938), 91-102, p. 92.

Oliveras Devesa, Mario, La recuperación de mutilados (San Sebastián, 1939.

Oliveras Devesa, Mario, Traumatismos e incapacidades de la mano (Barcelona, 1948).

Oller, Antonio, "Algunos comentarios a la Ley de accidentes del trabajo", Los Progresos de la Clínica, 12 (1918), 372-380.

Oller, Antonio, Memoria de la Clínica del Trabajo del INP (1933-1934) (Madrid, 1935).

Oller, Antonio, Memoria de la Clínica del Trabajo del INP (1935) (Madrid, 1936).

Ott, Katherine,,Serlin, David and Mihm, Stephen, eds., Artificial Parts, practical lives. Modern Histories Prosthetics (New York \& London, 2002), 
Palacios Sánchez, Julián, "Evolución histórica”, in Julián Palacios Sánchez (coord.), Historia del C.P.E.E. de Reeducación de Inválidos. Antiguo INRI, (Madrid, undated), pp. 51-59.

Palacios Sánchez, Julián, La institución pionera de la Rehabilitación en España, (Madrid, 1990).

Perry, Heather R, "Re-Arming the Disabled Veteran. Artificially Rebuilding State and Society in World War One Germany", in Ott, Katherine,,Serlin, David and Mihm, Stephen, eds., Artificial Parts, practical lives. Modern Histories Prosthetics (New York \& London, 2002), pp. 75-101.

Polo Griñán, Cándido, "La Psiquiatría en las Brigadas Internacionales", in Ricardo Campos, Olga Villasante and Rafael Huertas, eds., De la 'Edad de Plata' al exilio. Construcción y 'reconstrucción' de la Psiquiatría española (Madrid, 2007), pp. 211-237.

Ponencia, Primera, Recuperación quirúrgico-ortopédica de los mutilados de guerra, (Madrid, 1941).

Porras Gallo, María Isabel, "La Medicina y los Seguros sociales en el abordaje del problema de los inválidos del trabajo en España en la primera mitad del siglo XX”, História. Ciências, Saúde-Manguinhos, 13-2 (2006), 393-410.

Porras Gallo María Isabel, "Medicina, guerra y reintegración social del inválido del trabajo en la España del primer cuarto del siglo XX", in Ricardo Campos, Luis Montiel and Rafael Huertas, coords., Medicina, ideología e historia en España (Siglos XVI-XXI). (Madrid, 2007), pp. 525-539;

Porras Gallo, María Isabel "Medicine and the social reintegration of the working disabled into the workforce in France and Spain", in Laurinda Abreu and Patrice Bourdelais, eds., The Price of Life. Welfare Systems, Social Nets and Economic Growth. (Lisboa, 2008), pp. 163-186.

Porras-Gallo, María-Isabel, "The role of the Spanish Red Cross in the establishment of a system of specialized health care for war disabled and invalids: from the colonial disaster to the African war", in Pilar León Sanz (ed.), Health Institutions at the Origen of the Welfare Systems in Europe, (Pamplona, 2010), pp. 131-149.

Proyecto de Ley leído por el Sr. Ministro de la Gobernación modificando la de 30 de enero de 1900 sobre accidentes del trabajo, Diario de las Sesiones de las Cortes. Congreso de los Diputados, 34 (18-11-1919). Apéndice 3º.

Pruneda, J., "Los Servicios de Cirugía Ortopédica y Reeducación", Revista Española de Medicina y Cirugía de Guerra, 15 (1939), 372-376, p. 372.

Reznick, Jeffrey S, "Work-Therapy and the Disabled British Soldier in Great Britain in the First World War: The Case of Shepherd's Bush Military Hospital, London” in Gerber, David A, ed., Disabled veterans in history (Michigan, 2000), pp. 185-203. 
Ruano Hernández, Ángel, Invalidez, desamparo e indefensión en seres humanos (Madrid, 1993).

Stiker, Henri-Jacques, Corps infirmes et sociétés (first edition, Paris: Aubier Montagne, 1982), (Paris, 1997).

Torres Medina, José María coord., Gómez Ulla. Hospital Militar Central. Cien años de Historia 1896-1996 (Madrid, 1996), pp. 136-137;

Trabal, Antonio , Breve historial de la Liga de Mutilados e Inválidos de la Guerra de España (Barcelona, 1986).

Valdés Larrañaga, Manuel, De la Falange al Movimiento (1936-1952) (Madrid, 1994), p. 134.

Vega, Pedro, Historia de la Liga de Mutilados (Madrid, 1981).

Verville, Richard, War, politics and philanthropy: the history of rehabilitation medicine (Lanham, 2009). 